\title{
Effectiveness of Reducing P Fertilizer and Adding Fish Pond Mud Waste on Growth and Yield of Soybean in Peatland
}

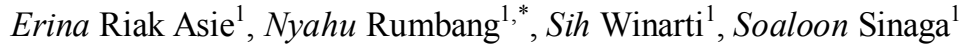 \\ Faculty of Agriculture, University of Palangka Raya, Indonesia
}

\begin{abstract}
The objective of the study was to assess the effectiveness of $\mathrm{P}$ fertilizer reduction and the addition of fish pond sludge waste on the growth and yield of soybean crop in peatland. Research used Complete Randomized Design factorial with two factors. The first factor was the reduction of P fertilizer from the dose of $150 \mathrm{~kg} \cdot \mathrm{ha}^{-1}$ consisting of 4 levels, namely P0: 100\% (2.944 g/polybag), P1: 75\% (2.208 g/polybag), P2: 50\% (1.472 g/polybag), and P3: 25\% (0.736 g/polybag). The second factor was the addition of fish pond mud waste (L) from the dose of 15 ton.ha ${ }^{-1}$ consisting of 4 levels, namely L0: $25 \%$ (73.595 g/polybag), L1: 50\% (147.19 g/polybag), L2: 75\% (220.78 g/polybag), and L3: 100\% (294.38 $\mathrm{g} /$ polybag). Each treatment combination was replicated 3 times to obtain 48 experimental units. The results showed that (1) fish pond mud waste was effective to reduce the use of P fertilizer, (2) the reduction of $\mathrm{P}$ fertilizer up to $50 \%$ from recommendation dosage by addition of fish pond sludge waste at $75 \%$ dose of 15 ton/ha was the best combination due to providing the best plant growth and the highest $\mathrm{P}$ concentration of plant tissue. The highest number of pods and weight of seed obtained in the combination were 60.33 pods/plant and $7.30 \mathrm{~g} / \mathrm{plant}$, respectively.
\end{abstract}

\section{Introduction}

The soybean crop (Glycine $\max (\mathrm{L}$.$) is a high-quality$ vegetable-producing plant of high-quality vegetable protein, but until now, the domestic soybean requirement is highly dependent on imports. Efforts to reduce the volume of soybean imports are the extensive cultivation system and yield improvement through the application of appropriate cultivation technology.

The conversion of peatlands into agricultural land has been increasingly difficult to avoid as a result of the food availability fulfillment. Peat swamp forest conversion to other land uses comes at a great cost in terms of large quantities of greenhouse gas emissions [1]. Utilization of peatlands as agricultural land has threatened the ecological function of peat as a carbon store, because it releases $\mathrm{CO}_{2}$ into the atmosphere, which contributes substantially to greenhouse gases.

Peatland utilization as agricultural land is constrained by peat fertility low levels so that application of high amount of lime and inorganic fertilizer input should be conducted. Substantial organic matter decomposition occurs in both oxic and anoxic conditions in tropical peat [2]. Rewetting of organic soils results in a decrease in $\mathrm{CO}_{2}$ and $\mathrm{N}_{2} \mathrm{O}$ emissions, DOC losses and GHG emissions based on the global warming potential but also leads to an increase in $\mathrm{CH}_{4}$ emissions [3].

Another alternative used as ameliorant as well as substitution of the plant nutrient, especially $\mathrm{P}$ element is fish pond mud waste. Aquaculture activity produced significantly $\mathrm{N}$ and $\mathrm{P}$ affecting not only the quality of peatland water, but also the environment as a whole. The levels of $\mathrm{N}$ and $\mathrm{P}$ on fish food and the efficiency used by fish affected the amount of these elements excreted into the environment [4].The other research showed that the nutrient content of $\mathrm{P}$ in fish pond sludge was very high, ie $309.68 \mathrm{ppm}$ and 6 times higher than $\mathrm{P}$ in peat soil about $40.93 \mathrm{ppm}$. Furthermore, the combination of fish pond mud sediment and peat resulted in a sharp growth of red dragon fruit plant in line with the increasing volume of sediment pond sludge [5]. Combination of mud and fish pond water before planting sweet potato and corn may increase the $\mathrm{C}$-organic, $\mathrm{N}$-total, $\mathrm{P}$-Bray, CEC, and base content in the soil [6]

Mud of fish pond is one of aquacultural waste that has not been widely used for agricultural activities, because farmers have not known the potential nutrient content in fish pond mud. However, fish pond mud was rich in humid content and feed residues that contained lots of nutrients N, P, and K [7]. Therefore, mud of fish ponds was potential to be utilized as ameliorant and to

*Corresponding author: nyahurumbang@yahoo.com 
substitute inorganic fertilizers, especially $\mathrm{P}$ fertilizers that may reduce the use of inorganic fertilizers which in turn may reduce production costs buying fertilizer and lime. In addition, the utilization of fish pond sludge waste for crop cultivation was not only proposed at improving peatland chemical properties, but also as waste management efforts.

\section{Materials and Methods}

The study was conducted from May - September 2016 in Palangka Raya, Central Kalimantan Province. The materials used were varieties of Wilis soybean seeds, fish pond mud waste, SP-36 fertilizer, Urea, $\mathrm{KCl}$, and Furadan. The equipments used were $\mathrm{pH}$ meter, meter, ruler, paper label, analytical scale, polybag size $50 \mathrm{~cm}$ x $50 \mathrm{~cm}$. Complete Randomized Design (CRD) factorial with two factors was applied. The first factor was the reduction of the dosage of SP-36 (P) from the recommended dose of $150 \mathrm{~kg} / \mathrm{ha}$, consisting of 4 levels, P0: $\quad 100 \% \quad(2.944$ g/polybag), P1: $\quad 75 \% \quad(2.208$ g/polybag), P2: 50\% (1.472g/polybag), and P3: $25 \%$ $(0.736 \mathrm{~g} / \mathrm{polybag})$. The second factor was the addition of fish pond mud (L) from the dose of 15 ton/ha, consisting of 4 levels, namely L0: $25 \% \quad(73.595$ g/polybag), L1: 50\% (147.19 g/polybag), L2 : 75\% (220.78 g/polybag), and L3: 100\% (294.38 g/polybag), so there were 16 treatment combinations with three replications. The data were analyzed using variance analysis ( $\mathrm{F}$ test) at $\alpha=5 \%$ and followed by LSD test. In all Figures, the same small letters upper each column were not significantly different according to the LSD test $\alpha=0.05$.

\section{Results and Discussion}

\subsection{Root Volume}

The effect of the interaction between the reduction of $P$ fertilizer and the addition of fish pond sludge was significantly shown. The volume of soybean roots at the lowest dosage of fish pond sludge $(25 \%)$ at various given $\mathrm{P}$ fertilizer doses was quite different from that of the volume of plant roots given fish pond sludge at higher doses (Figure 1). This was closely related to the fish pond mud ability to improve the fertility of peat chemicals such as increasing $\mathrm{pH}$ and increasing the amount of nutrients in the planting media. Accumulation of fish pond sludge was rich in nutrients and organic matter and potentially as ameliorant. Porous texture of peat and fine texture and clay from fish pond mud may be complement each other in improving the physical properties of planting media, so that aeration and absorption capacity of water and nutrients may be better, which in turn the roots of plants may grow well [7]. The combination of Pfertilizer application at moderate dose $(50 \%)$ and fish pond mud at $75 \%$ was able to give the best root volume, ie $19.66 \mathrm{~mL} /$ plant (Figure 1)

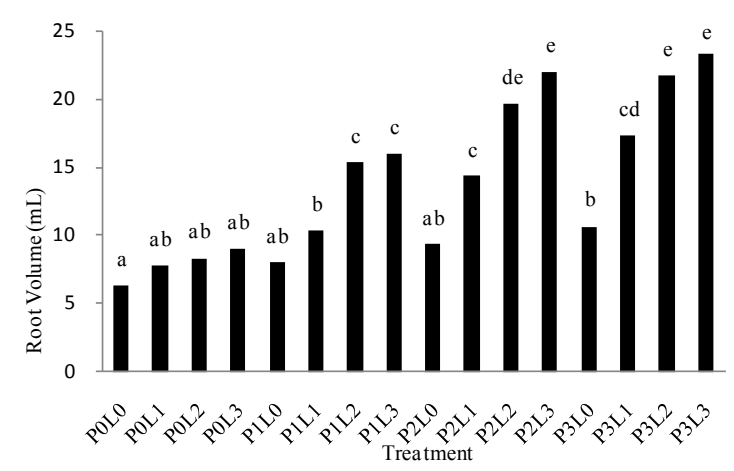

Fig. 1. Root volume

\subsection{Shoot Dry Weight}

The effect of the interaction between the reduction of $P$ fertilizer and the addition of fish pond sludge to the dry weight of the shoot was seen (Figure 2).An increase in the dry weight of the shoot due to the increase in fish pond sludge was caused by the addition of fish pond sludge and P fertilizer that caused an increase in supply and availability of $\mathrm{N}$ and $\mathrm{P}$ nutrients. In addition, fish pond mud may improve soil physical properties that may cause a good impact on the growth and development of plant root systems, so that nutrient uptake may also increase. Increased nutrient uptake, especially $\mathrm{N}$, increased the formation of chlorophyll so that the rate of photosynthesis increased and in turn the more biomass was produced. The $\mathrm{P}$ element was needed to activate plant metabolism processes such as photosynthesis due to its presence in the ATP used to reduce $\mathrm{CO}_{2}$ to carbohydrates, so that increased the formation of plant biomass, which was seen with the increase in dry weight of the plant shoot. The provision of marine sludge was able to increase the growth and yield of soybean crops on peat soils [8]

Plant $\mathrm{P}$ concentration was higher with higher doses of fish pond sludge given up to $75 \%$ of the 15 ton/ha doses and the application of $\mathrm{P}$ fertilizer at a dose of $50 \%$ of the recommended dose (Figure 3). Application of fish pond sludge up to $75 \%$ dosage was expected to increase the soil $\mathrm{P}$ content. This was due to the high content of $\mathrm{P}$ in fish pond mud. The P content of fish pond sludge was $309.68 \mathrm{ppm}$ [5]. In addition to the supply of $\mathrm{P}$ derived from fish pond sludge, $\mathrm{P}$ was also added through SP-36 fertilization. Therefore, the combination of $\mathrm{P}$ at $50 \%$ dosage and fish pond sludge at $75 \%$ dosage was able to increase the availability of $P$ soil so that the $\mathrm{P}$ concentration in soybean plant tissue grown on the combination of treatments showed the highest value of $2402.97 \mathrm{ppm}$ or $0.2402 \%$, classified as adequate [9] . Phospor absorption by plants was an interconnected simultaneous process between P-soil, $\mathrm{P}$ diffusion flow and plant metabolism [10]. The increase of $\mathrm{P}$ uptake by soybean plants in combination of $50 \% \mathrm{P}$ treatment and $75 \%$ of fish pond sludge was related to good root system development. The root of the soybean crop with a large root volume on the combination of treatments was obtained (Figure 1). The root system development, especially hair root growth, was influenced by the distribution of nutrients, especially $\mathrm{P}$ 
element. With a good root system development, the root ability to reach or obtain nutrients was greater, so the absorption and concentration of $\mathrm{P}$ on the soybean plant tissue were to be better [11]

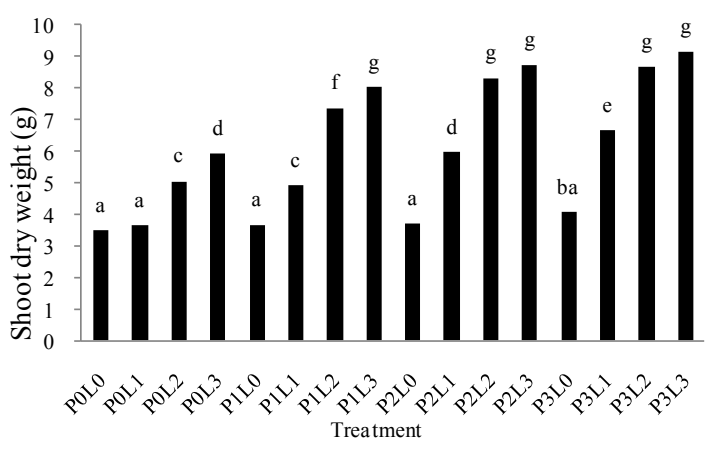

Fig. 2. Shoot dry weight

\subsection{Plant Tissue P Concentration}

Plant P concentration was higher with higher doses of fish pond sludge given up to $75 \%$ of the 15 ton/ha doses and the application of $\mathrm{P}$ fertilizer at a dose of $50 \%$ of the recommended dose (Figure 3). Application of fish pond sludge up to $75 \%$ dosage was expected to increase the soil $\mathrm{P}$ content. This was due to the high content of $\mathrm{P}$ in fish pond mud. The $\mathrm{P}$ content of fish pond sludge was $309.68 \mathrm{ppm}$ [5]. In addition to the supply of $\mathrm{P}$ derived from fish pond sludge, $\mathrm{P}$ was also added through SP-36 fertilization. Therefore, the combination of $\mathrm{P}$ at $50 \%$ dosage and fish pond sludge at $75 \%$ dosage was able to increase the availability of $P$ soil so that the $\mathrm{P}$ concentration in soybean plant tissue grown on the combination of treatments showed the highest value of $2402.97 \mathrm{ppm}$ or $0.2402 \%$, classified as adequate [9].

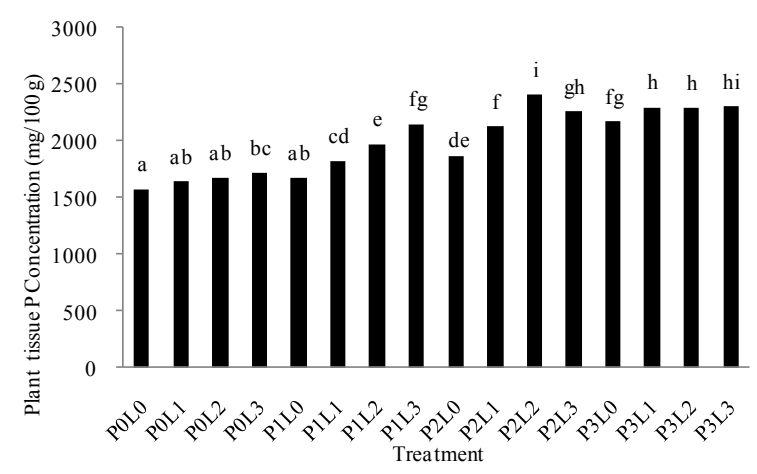

Fig 3. Plant tissue $\mathrm{P}$ Concentration

Phospor absorption by plants was an interconnected simultaneous process between P-soil, $\mathrm{P}$ diffusion flow and plant metabolism [6]. The increase of $\mathrm{P}$ uptake by soybean plants in combination of $50 \% \mathrm{P}$ treatment and $75 \%$ of fish pond sludge was related to good root system development. The root of the soybean crop with a large root volume on the combination of treatments was obtained (Figure 1). Root system development, especially hair root growth, was influenced by the distribution of nutrients, especially $\mathrm{P}$ element. With a good root system development, the root ability to reach or obtain nutrients was greater, so the absorption and concentration of $\mathrm{P}$ on the soybean plant tissue were to be better [11].

\subsection{Number of pods per plant}

The number of pods per plant was more in line with higher doses of fish pond sludge given from $25 \%$ to $75 \%$ dosage on $\mathrm{P}$ fertilizer as much as $50 \%$ of recommended dosage (Figure 4).Root volume, shoot dry weight and $\mathrm{P}$ concentration of soybean tissue given fish pond sludge increased up to $75 \%$ dosage along with medium-dose $(50 \%$ recommended dose $)$ of $\mathrm{P}$ fertilizer (Figure 1 and 2). It is seemed that this caused the growth of soybean crops better and then may produce more pods of content. Supply P derived from fish pond mud and $\mathrm{P}$ fertilizer may increase the availability of $\mathrm{P}$-soil. In addition to $\mathrm{P}$ element, fish pond mud also contained elements of $\mathrm{N}$ and $\mathrm{K}$ [7]. $\mathrm{P}$ element may play a role in the formation of plant generative organs such as pods. However, the $\mathrm{K}$ element acted as an activator of various essential enzymes in photosynthetic and respiratory reactions and functions in photosynthesis translocation. $\mathrm{K}$ mud of fish pond was relatively high about $1.43 \mathrm{me} / 100 \mathrm{~g}$ [5].

The photosynthesis process may run well with the fulfillment $\mathrm{P}$ and $\mathrm{K}$ element, and other nutrients so that the photosynthesis result also increased. The photosynthesis result was partially transferred to the plant generative parts for the pod feeding process so that the number of pods per plant increased. The highest number of pods was obtained in a combination of $75 \%$ fish pond mud and $50 \%$ of $P$ fertilizer, ie 60.33 pods.

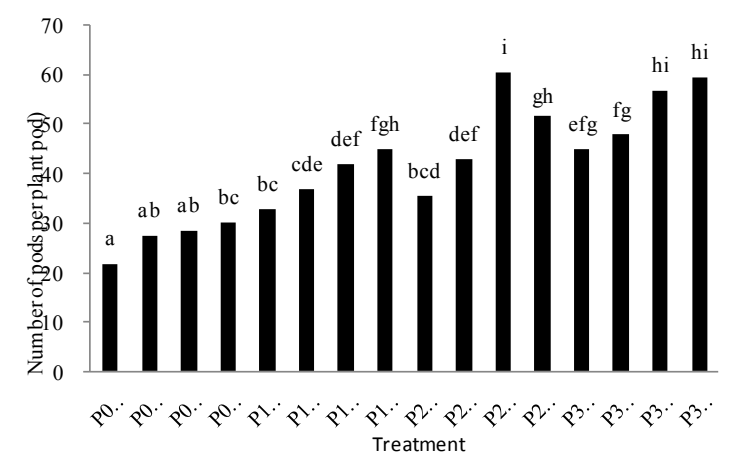

Fig 4. Number of pods per plant

\subsection{Dry Seed Weight per Plant}

The response of dry seeds of soybean crops to $\mathrm{P}$ fertilizer application was increase along with the increase of fish pond sludge added from $25 \%$ dosage up to $75 \%$ dose (Figure 5). This was due to the improvement of physical, chemical and biological properties of peat soil coming from fish pond mud. The presence of basic cations such as $\mathrm{Ca}$ in fish pond mud potentially increased the saturation of the peat soil base, so that soil $\mathrm{pH}$ increased. An increase in soil $\mathrm{pH}$ 
may accelerate the development of microbes in the soil that will improve the process of peatland decomposition. Use of sludge from sea increased the $\mathrm{pH}$ of the peat so that it may spur the development of bacteria in peat soil causing a decrease $\mathrm{C} / \mathrm{N}$ ratio of peat soil [12].

An increase in soil $\mathrm{pH}$ may also affect the availability of other nutrients such as $\mathrm{N}, \mathrm{P}, \mathrm{K}, \mathrm{Ca}$, and $\mathrm{Mg}$ [13]. The increase of N, P, and K elements due to the application of $\mathrm{P}$ fertilizer and fish pond sludge caused the photosynthesis process to occur smoothly so that the photosynthesis may meet the needs of plants for growth and development balanced by translocation of most photosynthesis result to the generative, so that the crop may be improved. Proper supply of nutrients may greatly assist plant growth to achieve high yields. Soybean plants applied fish pond sludge at $75 \%$ dose with P fertilizer at moderate dose $(50 \%)$ showed better growth. Plants with good growth may provide a high yield, because the result was a manifestation of growth. The highest yield of dry seeds per plant in this study was obtained on medium dosage of $\mathrm{P}$ fertilizer $(50 \%)$ and pond sludge at $75 \%$, ie $7.30 \mathrm{~g} /$ plant.

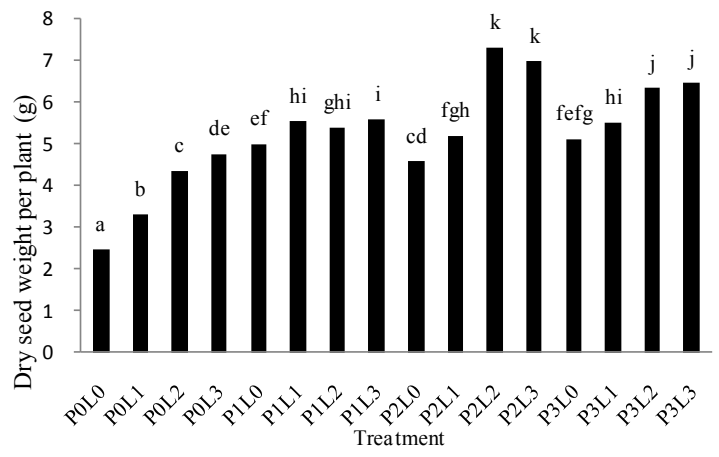

Fig 5. Dry seed weight per plant

\section{Conclusion and Suggestion}

\subsection{Conclusion}

1. Fish pond mud waste was effective to reduce the use of $P$ fertilizer on soybean cultivation in inland peatlands.

2. The reduction of $\mathrm{P}$ fertilizer to $50 \%$ of recommended dosage by addition of fish pond sludge with a dose of $75 \%$ was the best combination due to producing the best growth: the largest root volume and the heaviest dry weight of shoot, of $19.66 \mathrm{~mL} /$ plant and $8.33 \mathrm{~g} / \mathrm{plant}$, respectively.

3. The highest amount of plant tissue $P$ concentration, number of pods and dry seed yield per plant was obtained in combination of $\mathrm{P}$ fertilizer application at moderate dosage $(50 \%$ recommended dosage) and fish pond mud at $75 \%$, namely $2402.97 \mathrm{ppm} /$ plant, 60.33 pods/plant and $7.30 \mathrm{~g} /$ plant, respectively.

\subsection{Suggestion}

1. Fish pond mud waste may be used not only as ameliorant, but also as alternative material to add $P$ nutrient.

2. For the soybean crop cultivation in the peat soil it is advisable to provide $\mathrm{P}$ fertilizer with a dosage of $50 \%$ recommendation dosage along with the fish pond mud with $75 \%$ of the dose 15 ton/ha,

3. Further research to study the residual effect of fish pond sludge waste should be performed.

\section{Acknowledgments}

Authors thank to (1) Rudi Ansyah for assisting in field research, and (2) Palangka Raya University for providing financial support through DIPA PNBP Universitas Palangka Raya Fiscal Year 2016, No: 2899/UN24 /PL/2016, dated August 19, 2016.

\section{References}

1. I. Basuki, J. B. Kauffman, , D. Murdiyarso, G. Anshari. Proc $15^{\text {th }}$ International Peat Congress 2016: Peatlands in Harmovy, Agriculture, Industry and Nature. Kuching, Sarawak, Malaysia. 258-263 (2016)

2. J. Jauhiainen, H. Silvennoinen, M. Könönen, S. Limin, H. Vasander. Proc $15^{\text {th }}$ International Peat Congress 2016: Peatlands in Harmovy, Agriculture, Industry and Nature. Kuching, Sarawak, Malaysia. 127 -131 (2016)

3. J. O. Rieley, D. Wilson, D. Blain, J. Couwenberg, C. D. Evans, D. Murdiyarso, S. E. Page, F. Renou-Wilson, A. Sirin, M. Strack, E-S. Tuittila. Proc $15^{\text {th }}$ International Peat Congress 2016: Peatlands in Harmovy, Agriculture, Industry and Nature. Kuching, Sarawak, Malaysia. 301-306 (2016)

4. R. Lazzari, B. Baldisseroto. B.Inst. Pesca, Sao Paulo, 34(4) 591-600 (2008)

5. Nyahu, S. Sinaga, E. R. Asie. Aplikasi Kombinasi Endapan Lumpur Kolam Ikan dan Gambut Sebagai Amelioran dan Media Tanam Buah Naga Merah (Hylocereus sp.). Lembaga Penelitian Universitas Palangka Raya: Palangka Raya (2014)

6. S. H. Wijayanti. Perubahan sifat kimia tanah yang diberi perlakuan lumpur dan air kolam ikan dalam 2 kali penanaman di desa Petir, Dermaga. Bogor. http://repository.ipb.ac.id (verified 18 Feb.2016) (2015)

7. R. Sutanto R. Penerapan Pertanian Organik (Pemasyarakatan dan Pengembangannya). Kanisius. Yogyakarta. (2012)

8. T. Abdurrahman, Radian, M. Safwan, M. Pertumbuhan dan hasil kedelai dengan pernggunaan lumpur laut cair pada beberapa tingkat kematangan gambut. Pembangunan pertanian berkelanjutan berbasis kedaulan 
pangan dan energi untuk meningkatkan perekonomian nasional. Fakultas Pertanian Universitas Palangka Raya. 137-142 (2015)

9. B. Lakitan. Dasar-dasar Fisiologi Tumbuhan. Rajagrafindo Persada. Jakarta (1996)

10. S. A. Barber, S.A. Soil Nutrient Bioavailability. $2^{\text {nd }}$ Edition. Jhon Wiley and Sons, Inc. New York (1995)
11. P. J. Gregory. Root growth and activity. Physiology and Determination of Crop Yield. ASA,CSSA,SSSA, Madison, WI. 65-96 (1994)

12. T. Abdurrahman. Indonesian J. of Applied Science. 3(3) : 78-83 (2013)

13. K. A. Hanafiah. Dasar-dasar Ilmu Tanah. Rajagrafindo Persada. Jakarta (2004) 